\title{
PENGARUH LATIHAN SIRKUIT TERHADAP KEMAMPUAN DRIBBLE DALAM PERMAINAN SEPAK BOLA PADA SSB PUTERA SUKMA U-15 PALEMBANG
}

\author{
Heldika Raja Ihsan ${ }^{1}$, Syamsuramel ${ }^{2}$, Ahmad Richard Victorian $^{3}$ \\ ${ }^{123}$ Program Studi Pendidikan Jasmani dan Kesehatan, \\ Fakultas Keguruan Dan Ilmu Pendidikan, Universitas Sriwijaya \\ hrajaihsan@gmail.com ${ }^{1,}$ syamsurame10308@ gmail.com ${ }^{2} \underline{\text { Richardvictoriann@ }}$ fkip.unsri.ac.id $^{3}$
}

\begin{abstract}
ABSTRAK
Penelitian ini bertujuan untuk mengetahui pengaruh latihan zig-zag terhadap kemampuan dribble dalam permainan sepakbola pada SSB Putera Sukma U-15 Palembang. Populasi penelitian ini adalah pemain SSB Putera Sukma U-15 yang berjumlah 30 orang. Sampel dalam penelitiaan ini berjumlah 30 orang. Metode yang digunakan dalam penelitian ini adalah eksperimen semu (quasi experimen) dengan rancangan pretest dan posttest one group. Instrumen dalam penelitian ini adalah tes menggiring bola. Data diambil dari tes awal (pretest) dan tes akhir (posttest). Perlakuan dalam penelitian ini berupa latihan sirkuit diberikan latihan selama 6 minggu dengan frekuensi latihan 3 kali seminggu. Berdasarkan hasil penelitian dan analisis data statistik uji t dengan taraf signifikan $\alpha=0,05$ didapat $t_{\text {hitung }}(6,8)$ sedangkan $t_{\text {tabel }}(1,70)$, maka $t_{\text {hitung }}>t_{\text {tabel }}$ sehingga $H_{1}$ diterima dan $\mathrm{H}_{\mathrm{o}}$ ditolak. Dengan demikian $\mathrm{H}_{1}$ dapat diajukan dan dapat diterima, bahwa latihan sirkuit berpengaruh terhadap kemampuan dribble pada pemain SSB Putera Sukma U-15 Palembang. Implikasi dari penelitian ini bahwa latihan sirkuit dapat digunakan sebagai salah satu jenis latihan untuk meningkatkan kemampuan dribble.
\end{abstract}

Kata Kunci: Sepak bola, latihan sirkuit, dribble.

\section{ABSTRACT}

This study aims to see the effect of circuit training on dribbling skills in soccer games at SSB Putera Sukma U-15 Palembang. The population of this research is the SSB Putera Sukma U-15 players who want 30 people. The sample in this research may be 30 people. The method used in this research is quasi-experimental (quasiexperimental) with a one-group pretest and posttest design. The instrument in this study was the dribbling test. Data were taken from the pre-test and post-test. The treatment in this study was in the form of circuit training given for 6 weeks with a frequency of training 3 times a week. Based on the results of the research and statistical data analysis of the t test with a significant level of $\alpha=0.05$, it was obtained $t_{\text {count }}(6.8)$ while $t_{\text {table }}(1.70)$, then $t_{\text {count }}>t_{\text {table }}$ so that $H_{I}$ was accepted and $H o$ was rejected. Thus $H_{I}$ can be proposed and it can be accepted, that circuit training affects the dribbling agility (dribbling) of SSB Putera Sukma U-15 Palembang Players. The implication of this research is that circuit training can be used as a type of exercise to improve dribbling agility.

Keywords: Football, Circuit Training, Dribble.

Dipublikasikan Oleh :

UPT Publikasi dan Pengelolaan Jurnal

Universitas Islam Kalimantan Muhammad Arsyad Al-Banjari Banjarmasin 


\section{PENDAHULUAN}

Sepakbola adalah permainan yang dimainkan oleh dua tim yang saling berhadapan dengan beranggotakan 11 pemain, yang mana untuk menentukan kemenangan yaitu dengan mencetak gol sebanyak mungkin ke gawang lawan. Menurut Sutanto (2016) sepak bola merupakan olahraga yang sangat popular saat ini. Dari sekian banyak cabang olahraga, sepakbola menjadi olahraga paling diminati orang sedunia.

Olahraga yang satu ini telah dimainkan oleh lebih dari 200 negara di dunia. Tujuan dari sesi latihan adalah untuk mempersiapkan pemain dalam kompetisi, sehingga dalam pertandingan dapat memperlihatkan perkembangan taktik, teknik, fisik dan jiwa kebersamaan (Psychosocial)/ Mental dalam diri pemain (Scheunemann, 2011).

Olahraga sepakbola merupakan salah satu cabang olahraga yang paling banyak diminati penduduk dunia, tidak terkecuali di Indonesia, cabang olahraga ini dimainkan oleh 11 orang pemain dan dilakukan di sebuah lapangan berumput yang sangat luas (Rahmani, 2014).

Permainan sepakbola adalah permainan tim yang menuntut adanya kerjasama yang baik dan rapi. Sepakbola adalah permainan beregu, oleh karena itu kerjasama regu merupakan tuntutan permainan sepakbola yang harus dipenuhi kesebelasan yang menginginkan kemenangan (Daryanto, 2015). Menurut Batty (2014) sepakbola adalah sebuah permainan yang sederhana, dan rahasia permainan sepakbola yang baik adalah melakukan hal-hal sederhana dengan sebaik-baiknya.

Sepakbola merupakan permainan beregu yang mengutamakan kerjasama tim dan berusaha untuk memasukkan bola ke gawang lawan sebanyak-banyaknya dan mempertahakan gawang agar terhindar dari tidak kemasukan bola. Permainan sepakbola akan sangat membosankan apabila tidak ada pemain yang mempunyai keahlian khusus seperti dribble yang sangat lincah. Ada beberapa pemain sepakbola dunia yang memiliki dribble yang sangat menawan seperti Cristiano Ronaldo, Lionel Messi, Eden Hazard. Adapun pemain sepakbola nasional yang memiliki dribble yang sangat lincah dan cepat seperti Saddil Ramdani, Andik Virmansyah, Egy Melgiansyah, Asnawi Mangkualam.

Permainan sepakbola masa kini pemain dituntut untuk dapat menguasai bola lebih baik, sehingga peluang untuk menciptakan gol cukup besar. Salah satu teknik dalam permainan sepakbola yang sering digunakan dan merupakan teknik yang paling penting adalah dribbling. Dribbling dalam permainan sepakbola merupakan suatu upaya mendorong bola secara terputus-putus dan posisi bola tidak jauh dari kaki, diharuskan bergerak dengan lincah dan eksplosif guna mendukung strategi sebuah tim dalam melaksanakan variasi serangan maupun bertahan, sehingga membutuhkan dukungan fisik yang prima. Menggiring bola (dribbling) berguna untuk mengontrol bola dan menguasainya sampai seorang rekan satu tim bebas dan memberikannya dalam posisi yang lebih baik (Luxbacher dalam Eki \& M Haris, 2019)

Keterampilan dribbling dalam permainan sepakbola merupakan keterampilan yang cukup sulit di kembangkan, sehingga untuk dapat menguasai bola dalam teknik dribbling diperlukan sebuah metode latihan yang baik dan tepat yang dilakukan secara intensif serta didukung dengan kondisi fisik yang baik agar tujuan sepakbola dengan penguasaan bola yang baik akan tercapai. Kesigapan pemain dalam mengambil keputusan harusnya diuji terus-menerus karena pemain dituntut memiliki kepekaan yang tinggi terhadap perubahanperubahan situasi yang amat sering terjadi sepanjang permainan (Mubarok, 2018).

Dunia olahraga dikenal dengan berbagai macam/metode pelatihan untuk melatih berbagai komponenkomponen kondisi fisik antara lain : interval training, continuous training, weight training, circuit training dan sebagainya. Latihan yang disesuaikan dengan kebutuhan dari atlet sesuai dengan cabang olahraga sang atlet tersebut. Latihan sirkui ialah sebuah latihan berkembang program latihan yang di kembangkan oleh R.E. Morgan dan G.T. Anderson pada tahun 1953 di University of Leeds di Inggris (Suharjana, 2013).

Pelatihan sirkuit merupakan bentuk efesien dalam mengembangkan kekuatan, ketahanan aerobic dan anaerobik, dan elastisitas tubuh. Istilah dalam latihan sirkuit ialah cara latihan yang disusun berdasarkan beberapa jenis latihan yang berbeda-beda. Dengan melakukan jenis latihan ini memungkinkan para pelatih dapat menambah variasi untuk program latihan rutin (Balasingh dan Night, 2018).

Latihan sirkuit merupakan latihan yang menggunakan pos-pos, di setiap pos melakukan bentuk latihan yang berbeda-beda yang telah ditentukan (Soniawan \& Irawan, 2018). Dalam latihan sirkut ini banyak melibatkan berbagai kelompok otot seperti kekuatan dan kebugaran secara bersamaan (Naldi \& IRawan, 2020). Latihan sirkuit merupakan latihan yang melibatkan otot dan semua elemen kondisi fisik. Latihan sirkuit ini bentuknya latihannya yang terdiri dari beberapa pos atau sirkuit dengan setiap pos mempunyai model latihan yang berbeda-beda. Menurut (Sukerti et al., 2017) mengungkapkan bahwa latihan sirkuit adalah latihan yang di dalamnya terdapat berbagai gerakan yang berkesinambungan dan di batasi oleh istirahat pada setiap gerakan bentuk latihan dengan adanya latihan sirkuit akan berdampak positif terhadap keahlian dan memulihkan kondisi kesegaran fisik, ketahan, ketangkasan, dan keluwetan tubuh.

Dipublikasikan Oleh :

UPT Publikasi dan Pengelolaan Jurnal

Universitas Islam Kalimantan Muhammad Arsyad Al-Banjari Banjarmasin 
Latihan sirkuit merupakan latihan yang melibatkan otot dan semua elemen kondisi fisik. Latihan sirkuit ini bentuknya latihannya yang terdiri dari beberapa pos atau sirkuit dengan setiap pos mempunyai model latihan yang berbeda-beda.

Latihan merupakan suatu proses lanjutan yang meruakan gabungan dari exercise yang di program dengan baik dan menggunakan metode yang tepat (Agung Wibowo, 2019).

Latihan merupakan salah satu proses sistematis yang berguna untuk mempersiapkan kondisi atlet pada tingkat tertinggi penampilannya yang dilakukan secara berulang-ulang dengan beban yang semakin meningkat (Harsono dalam Syamsuramel, 2012).

Menurut Syafruddin (2013:64) prinsip-prinsip latihan yang perlu diperhatikan dalam proses latihan adalah sebagai berikut: (1) prinsip superkompensasi, (2) prinsip beban berlebih, (3) prinsip variasi beban, (4) prinsip individualisasi, (5) prinsip spesialisasi, (6) prinsip periodisasi dan teraturitas beban.

Beberapa tahun terakhir, Sekolah Sepak Bola (SSB) banyak berdiri di Indonesia terutama di Kota Palembang. Mulai dari SSB yang professional hingga yang hanya untuk memberikan pelatihan dasar sepakbola kepada anak-anak sekolah dasar. Keberadaan SSB diharapkan mampu mencetak para atlet sepakbola handal dan berkualitas, namun masih banyak yang harus dilakukan untuk mendapatkan calon pemain timnas yang berkualitas. Menurut Timo dikutip Udam (2017) kurikulum di buat supaya pelatih-pelatih dan pengurus klub terutama SSB di seluruh Indonesia bisa mendapatkan pemahaman tentang apa yang harus dilatih dan apa yang jangan dilatih bergantung pada usia anak didiknya.

Sekolah sepak bola (SSB) merupakan sebuah organisasi di bidang olahraga khususnya sepakbola yang memiliki fungsi mengembangkan potensi yang dimiliki oleh atlet. Tujuan sekolah sepakbola adalah untuk menghasilkan atlet yang berbakat atan memiliki kemampuan yang baik, mampu bersaing dengan sekolah sepakbola lainnya, dapat memuaskan masyarakat dan mempertahankan keberlangsungan hidup suatu organisasi khususnya di bidang sepakbola (Aprinova dan Hariadi, 2016).

Target khusus sekolah sepak bola (SSB) untuk mengumpulkan dan memperluas kesempatan bagi setiap pemainnya untuk menggali potensi yang ada di dalam diri siswa tersebut. Selain itu sekolah sepak bola (SSB) juga mengenalkan dan memberikan pemahaman yang tepat dalam bermain sepakbola yang baik (Santoso dan Lismadiana, 2016).

Pembinaan sepakbola di Indonesia dalam kurikulum filanesia membagi kelompok usia menjadi 4 fase (Pratama et al., 2020). Fase pertama merupakan fase kembiraan sepakbola untuk rentan usia 6-9 tahun. Fase kedua merupakan pengembangan keterampilan sepakbola kelompok usia 10-13 tahun. Fase ketiga merupakan fase pengembangan permainan sepakbola kelompok usia 14-17 tahun. Dan fase keempat merupaka fase penampilan kelompok usia 18 tahun ke atas (senior) (Pratama et al., 2020).

Berdasarkan hasil pengamatan pada saat berjalanannya proses latihan di Sekolah Sepak Bola (SSB) Putera Sukma Palembang terdapat beberapa permasalahan yaitu kurangnya kemampuan dribble pemain Sekolah Sepak Bola (SSB) Putera Sukma Palembang terlihat pada saat mereka latihan, kurangnya variasi latihan pada pemain Sekolah Sepak Bola (SSB) Putera Sukma Palembang dikarenakan latihan teknik dasar harus terbagi dengan teknik-teknik yang lain, pemain yang masih bermain secara individu serta teknik dribble belum baik.

Permasalahan dari pengamatan tersebut dapat di atasi dengan latihan yang lebih bervariatif. Salah satu cara untuk meningkatkan kemampuan dribble yaitu dengan pemberian metode latihan yang bervariatif seperti metode latihan sirkuit. Teknik ini biasanya dilakukan dengan cara melewati rintangan yang telah di buat sedemikian rupa. Berdasarkan latar belakang tersebut, maka peneliti meneliti tentang cabang olahraga sepakbola terkhususnya teknik dribble, ini sebagai awal untuk mendorong pemain dalam meningkatkan keterampilan dribble dengan baik dan optimal.

\section{METODE}

Jenis penelitian yang digunakan dalam penelitian kali ini ialah quasy experiment, dengan menggunakan rancangan penelitian "pretest dan posttest one group". Desain ini mengunakan pretest sebelum diberi perlakuan, dengan demikian hasil perlakuan dapat diketahui lebih akurat, karena membandingkan dengan keadaan sebelum diberi perlakuan. Penelitian ini bertujuan untuk mengetahui ada tidaknya pengaruh antara variabel bebas terhadap variabel terikat (independent variables dan dependens variables) (Sugiyono, 2017). Variabel penelitiannya terdiri dari latihan sirkuit (variabel bebas), sedangkan peningkatan kemampuan dribble (variabel terikat).

Penelitian ini adalah quasy eksperiment dengan mengunakan rancangan/desain penelitian "pretest dan posttest one group" (Sugiyono, 2019). Langkah awal yang dilakukan yaitu pengukuran (pretest), kemudian dilakukan perlakuan dalam jangka waktu tertentu, dan selanjutnya diteruskan dengan pengukuran kembali (posttest) untuk melihat ada atau tidaknya perbedaan sebelum dan sesudah pemberian perlakuan. Metode

\section{Dipublikasikan Oleh :}

UPT Publikasi dan Pengelolaan Jurnal

Universitas Islam Kalimantan Muhammad Arsyad Al-Banjari Banjarmasin 
eksperimen adalah metode yang memberikan atau menggunakan suatu gejala yang disebut latihan. Dengan latihan yang telah diberikan tersebut, akan terlihat hubungan sebab akibat sebagai pengaruh dari pelaksanaaan latihan. dalam penelitian ini bertujuan untuk mengetahui adakah Pengaruh latihan sirkuit terhadap kemampuan Dribble dalam permainan sepakbola pada SSB Putera Sukma U-15 Palembang.

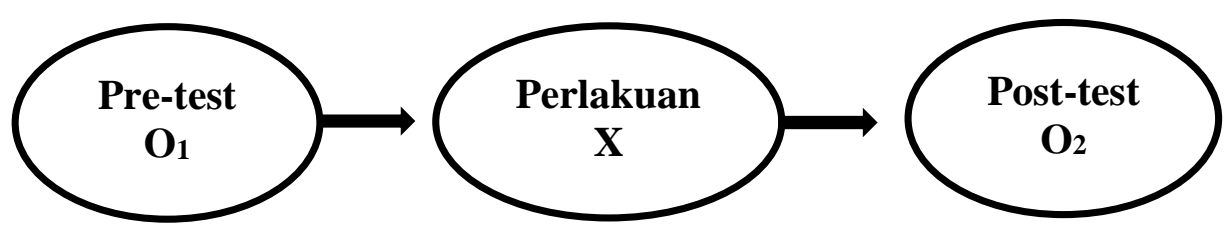

Gambar 3.1 Desain Penelitian

Sumber (Sugiyono, 2017)

Pelaksanaan tes kemampuan menggiring bola yaitu sebanyak 30 siswa melakukan menggiring bola dengan cara satu per satu melawati cone yang telah disusun dan dimulai dari titik start sampai finish untuk mengetahui prestasi awal maupun prestasi akhir. Data hasil yang didapatkan oleh siswa akan di catat dalam satuan waktu (menit). Adapun gambar circuit yang dilakukan dalam penelitian menggiring bola kali ini yaitu :

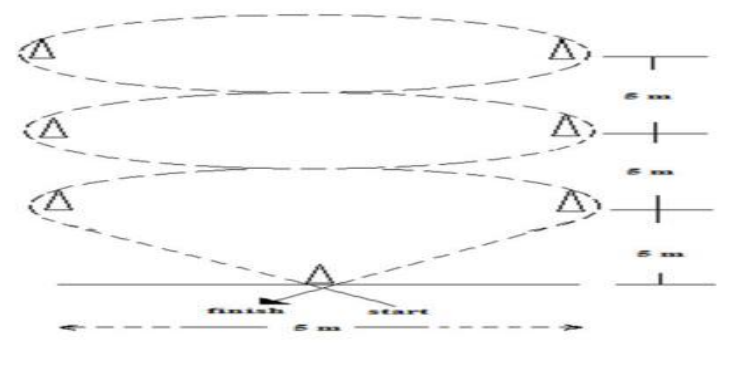

Gambar 3.2 Lintasan dalam tes menggiring bola

Sumber : Aryadie Adnan dalam Ikhsan, dkk. (2019)

Dalam hal ini populasi adalah wilayah generalisasi yang terdiri dari subjek/objek yang mempunyai kuantitas karakteristik tertentu yang ditetapkan oleh peneliti untuk dipelajari dan kemudian ditarik kesimpulanya. Jadi populasi bukan hanya orang, melainkan juga obyek dan benda-benda alam lainya. Populasi bukan sekedar jumlah yang ada pada objek/subjek yang dipelajari, tetapi meliputi seluruh karakteristik/sifat yang dimiliki oleh subyek atau obyek itu. Populasi dalam penelitian ini adalah seluruh pemain SSB Putera Sukma Palembang yang terdiri dari beberapa kelompok umur di mulau U-10-U-12 ada 20 orang, U-13-U14 ada 25 orang, U-15-U-16 ada 30 orang, maka seluruhnya berjumlah 75 orang. Pengambilan sampel dilakukan dengan cara purposive sampling, yaitu pengambilan sampel terdiri atas dasar ciri-ciri tertentu yang mempunyai hubungan dengan populasi yang sudah di ketahui. Bila populasi besar dan peneliti tidak mungkin mempelajari semua yang ada pada populasi, misalkan karena terbatas dana, tenaga, dan waktu, maka peneliti dapat menggunakan sampel yang diambil dari populasi itu. Sampel yang digunakan dalam penelitian kali ini adalah pemain U-15-U-16 tahun SSB Putera Sukma Palembang tahun 2021 sebanyak 30 orang. Pengambilan data ini akan dilakukan sebanyak 2 kali yaitu pada awal penelitian (pretest) dan akhir penelitian (posttest). Instrument atau alat ukur yang digunakan dalam penelitian ini adalah tes melewati cone dengan cara mendribble melewati cone yang telah di letakkan. Untuk mengetahui kemampuan dribble bola data hasil yang akan di catat dalam satuan waktu (menit).

Tabel 1. Norma dribbling zig-zag

\begin{tabular}{|l|l|}
\hline KATEGORI & PUTRA \\
\hline Baik sekali & $<18,99$ detik \\
\hline Baik & $19,00-21,00$ detik \\
\hline
\end{tabular}

Dipublikasikan Oleh :

UPT Publikasi dan Pengelolaan Jurnal

Universitas Islam Kalimantan Muhammad Arsyad Al-Banjari Banjarmasin 


\begin{tabular}{|c|c|}
\hline Sedang & 21,01-23,00 detik \\
\hline Kurang & 23,01-25,00 detik \\
\hline Kurang sekali & $>25,01$ detik \\
\hline
\end{tabular}

Sumber : Aryadie Adnan dalam Ikhsan, dkk. (2019)

\section{HASIL DAN PEMBAHASAN}

Penelitian ini dilaksanakan di lapangan sepakbola PGOT dinas sosial Palembang. Lokasi lapangan terletak di Jl. Residen H. Najmuddin No. 120A, Suka Maju, Kec. Sako, Kota Palembang, dengan rincian lapangan; panjang $100 \mathrm{~m}$ dan lebar 65 meter. Populasi dalam penelitian ini adalah pemain Sekolah Sepak Bola (SSB) Putera Sukma Palembang U-15. Setelah dilakukan tes awal atau pre-test, kemudian sampel yang berjumlah 30 orang diberikan program latihan selama enam minggu. Setelah enam minggu menjalankan program latihan, kemudian dilakukan tes akhir atau post-test. Pelaksanaan penelitian ini dilakukan pada tanggal 25 Februari 2021- 31 Maret 2021. Penelitian ini dilaksanakan selama enam minggu dengan 18 kali pertemuan pada setiap hari Senin, Rabu, dan Sabtu.

Pada saat awal penelitian, peneliti terlebih dahulu melakukan tes awal atau pre-test pada kelompok eksperimen, kemudian diberikan perlakuan berupa latihan sirkuit selama 6 minggu dengan frekuensi latihan 3 kali seminggu setelah itu dilakukan tes akhir atau posttest untuk melihat ada atau tidaknya perubahan setelah diberikan perlakuan, berikut ini adalah hasil prestest kelompok eksperimen, hasil tes awal (pretest) kecepatan tertinggi 16,21 dan kecepatan terendah 22,45 dengan rata-rata 18.83, perbedaan tes awal (pretest) dan tes akhir (posttest) kecepatan tertinggi 14,54 dan kecepatan terendah 20,59 dengan rata-rata 17,56. Berikut tabel perbandingan antara pretest dan posttest kelompok eksperimen.

Tabel 2. Distribusi Data Instrumen Tes Menggiring Bola (Pre-Test)

\begin{tabular}{|c|c|c|c|c|c|c|}
\hline Variabel & $\mathbf{N}$ & Jumlah Tertinggi & $\begin{array}{c}\text { Jumlah } \\
\text { Terendah }\end{array}$ & Rentangan & Mean & SB \\
\hline Menggiring Bola & 30 & 16,21 & 22,45 & 6,24 & 18,83 & 17,69 \\
\hline
\end{tabular}

Berdasarkan tabel 14.1 dapat diketaui jumlah nilai tertinggi 16,21 , jumlah nilai terendah 22,45 , rentangannya 6,24, rata-rata yang didapat dari pre-test yaitu 18,83 dan simpangan baku yang didapatkan dari hasil pre-test yaitu 17,69.

Berdasarkan daftar distribusi pre-test, dapat digambarkan dalam sebuah histogram sebagai berikut:

Dipublikasikan Oleh :

UPT Publikasi dan Pengelolaan Jurnal

Universitas Islam Kalimantan Muhammad Arsyad Al-Banjari Banjarmasin 


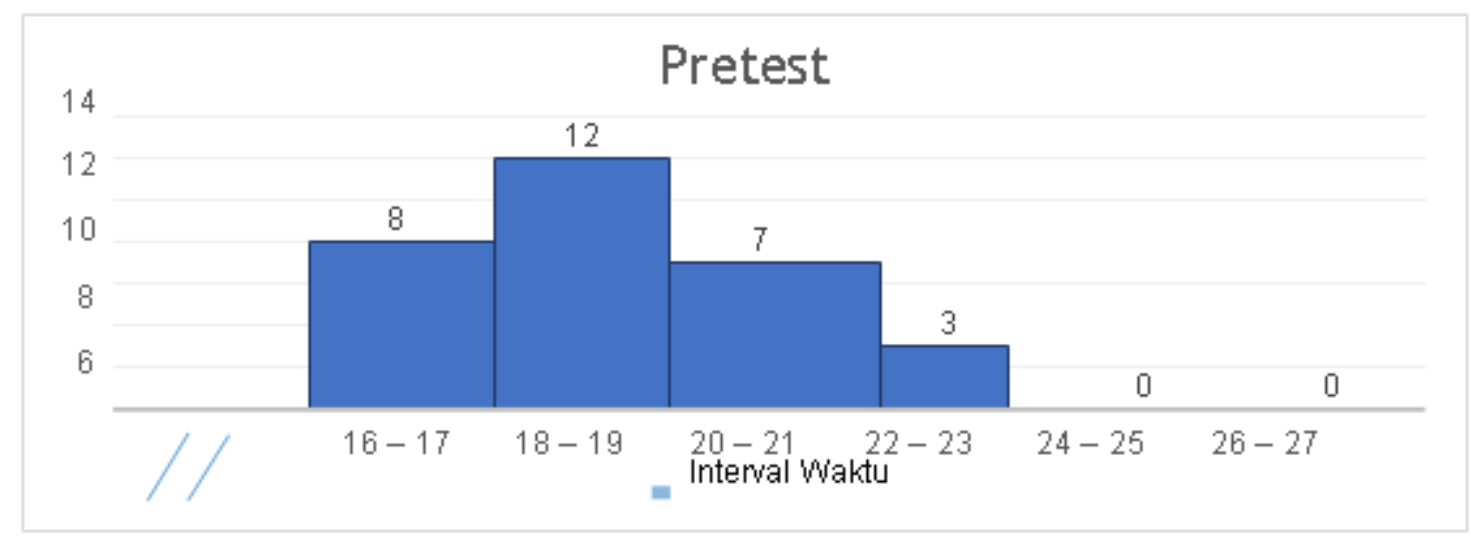

Gambar 4.1 Histogram Menggiring Bola (Pre-test)

Berdasarkan data yang di dapat pada pre-test menggiring bola , nilai tengah 16,5 (interval 16-17) terdapat 8 orang, nilai tengah 18,5 (interval 18-19) terdapat 12 orang, nilai tengah 20,5 (interval 20-21) terdapat 7 orang, nilai tengah 22,5 (interval 22-23) terdapat 3 orang, nilai tengah 24,5 (interval 24-25) terdapat 0 orang, nilai tengah 26,5 (interval 26-27) terdapat 0 orang.

Tabel 3. Distribusi Data Instrumen Tes Menggiring Bola (Posttest)

\begin{tabular}{|c|c|c|c|c|c|c|}
\hline Variabel & $\mathrm{N}$ & $\begin{array}{c}\text { Kecepatan } \\
\text { Tertinggi }\end{array}$ & $\begin{array}{c}\text { Kecepatan } \\
\text { Terendah }\end{array}$ & Rentangan & Mean & SB \\
\hline $\begin{array}{c}\text { Menggiring } \\
\text { bola }\end{array}$ & 30 & 14,54 & 20,59 & 6,05 & 23,35 & 29,577 \\
\hline
\end{tabular}

Berdasarkan tabel 4.3 dapat diketahui bahwa jumlai kecepatan tertinggi 14,54, jumlah kecepatan terendah 20,59, rentangnya sebesar 6,05, rata-rata yang di dapat dari posttest yaitu 23,35 serta simpangan baku yang di dapatkan dari hasil posttest yaitu 29,577

Berdasarkan tabel daftar distribusi hasil tes menggiring bola (posttest), dapat di gambarkan dalam sebuah histogram sebagai berikut :

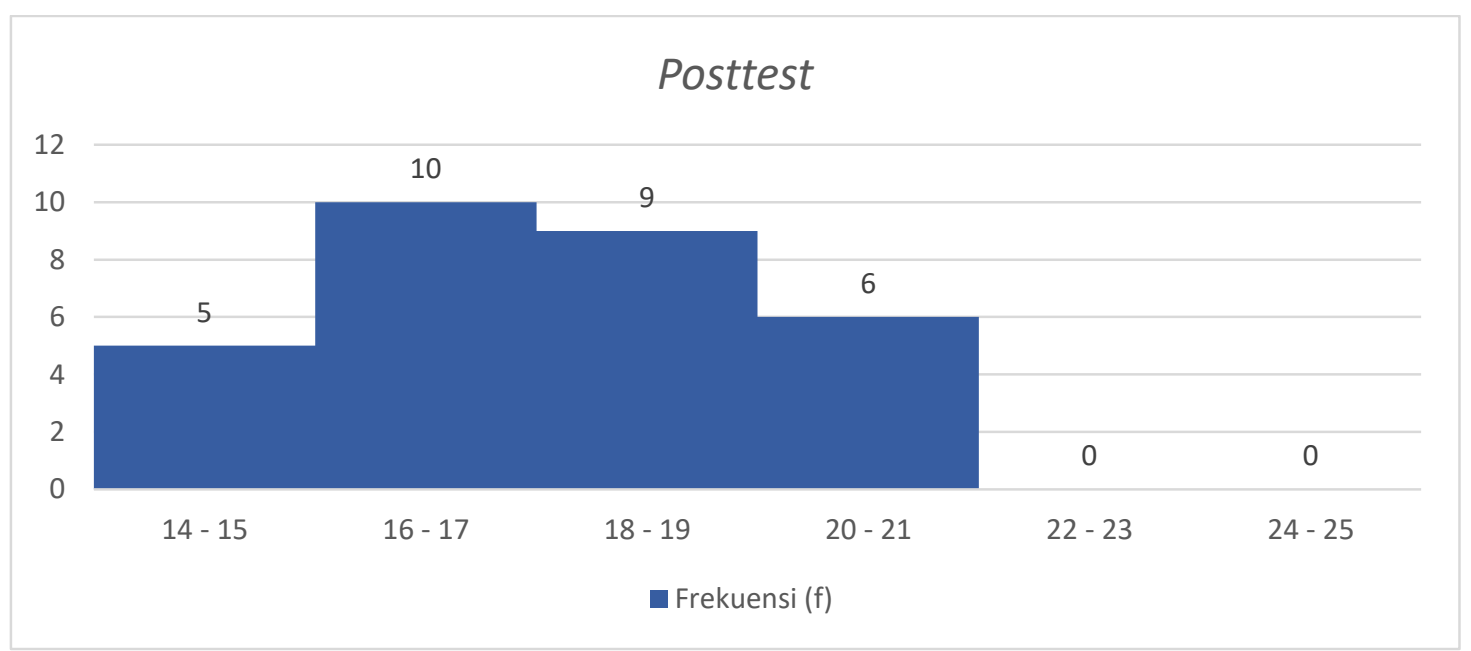

\section{Gambar 4.2 Histogram Menggiring Bola (Posttest)}

Berdasarkan data yang di dapat pada gambar di atas hasil menggiring bola (posttest), nilai tengah 14,5 (interval 14-15) terdapat 5 orang, nilai tengah 16,5 (interval 16-17) terdapat 10 orang, nilai tengah 18,5 (interval 18-19) terdapat 9 orang, nilai tengah 20,5 (interval 20-21) terdapat 6 orang, nilai tengah 22,5 (interval 22-23) terdapat 0 orang, nilai tengah 24,5 (interval 24-25) terdapat 0 orang.

Dipublikasikan Oleh :

UPT Publikasi dan Pengelolaan Jurnal

Universitas Islam Kalimantan Muhammad Arsyad Al-Banjari Banjarmasin 
Tabel 4. Daftar Perbandingan Hasil Pretest dan Posttest

\begin{tabular}{|l|l|l|l|l|l|}
\hline Hasil & N & $\begin{array}{l}\text { Kecepatan } \\
\text { Tertinggi }\end{array}$ & Kecepatan Terendah & Mean & $\begin{array}{l}\text { Perbedaan Mean Pretest } \\
\text { dan Posttest }\end{array}$ \\
\hline Pretest & 30 & 16,21 & 22,45 & 18,83 & \multirow{2}{*}{1,27} \\
\hline Posttest & 30 & 14,54 & 20,59 & 17,56 & \\
\hline
\end{tabular}

Perbandingan hasil pretest dan posttest di atas dapat di lihat hasil perbandingannya dari pretest jumlah kecepatan tertinggi yaitu 16,21 kecepatan terendah 22,45. Data hasil posttest kecepatan tertinggi yaitu 14,54 dan kecepatan terendah 20,59 dan di dapatlah rata-rata dari pretest sebesar 18,83 dan posttest sebesar 17,56 sehingga perbedaan mean pretest dan posttest sebesar 1,27.

Hasil data pretest kelompok eksperimen dengan kecepatan tertinggi 16,21 dan kecepatan terendah 22,45 dengan rata-rata 18,83, modus 17,49, standar deviasi 17,69, dan kemiringan kurva 0,7. Sedangkan data posttest kelompok eksperimen dengan kecepatan tertinggi 14,54, dan kecepatan terendah 20,59, dengan rata-rata 17,56, modus 15,88, standar deviasi 16,01, dan kemiringan kurva 0,8. Berikut gambar tabel perbandingan antara pretest dan posttest kelompok eksperimen :

Tabel 5. Daftar Peningkatan Hasil Pretest dan Posttest

\begin{tabular}{|l|l|l|l|l|l|l|l|}
\hline Hasil & N & $\begin{array}{l}\text { Kecepatan } \\
\text { Tertinggi }\end{array}$ & $\begin{array}{l}\text { Kecepatan } \\
\text { Terendah }\end{array}$ & Mean & $\begin{array}{l}\text { Peningkatan mean } \\
\text { pretest } \text { dan posttest }\end{array}$ & Modus & SD \\
\cline { 1 - 4 } Pretest & 30 & 16,21 & 22,45 & 18,83 & \multirow{2}{*}{1,27} & 17,49 & 17,69 \\
\hline Posttest & 30 & 14,54 & 20,59 & 17,56 & & 15,88 & 20,61 \\
\hline
\end{tabular}

Data perbandingan hasil pretest dan posttest dengan jumlah N sebanyak 30. Dapat dilihat pada tabel di atas hasil pretest dengan kecepatan tertinggi 16,21 dan kecepatan terendah 22,45, dengan mean 18,83, modus 17,49, dan standar deviasi 17,69. Data hasil posttest dengan kecepatan tertinggi 14,54 dan kecepatan terendah 20,59 dengan mean 17,56, modus 17,49, dan standar deviasi 17,69. Sehingga di dapatkan kenaikan mean pretest dan posttest sebessar 1,27.

Tabel 6. Deskriptif Statistik

\begin{tabular}{|c|c|c|c|c|c|}
\hline \multicolumn{5}{|c|}{ Statistik Hasil Dribble } & \multirow[b]{2}{*}{$\Sigma x d^{2}$} \\
\hline & $\mathbf{N}$ & Mean & $\Sigma \mathbf{d}$ & $\Sigma x d$ & \\
\hline Pretest & 30 & 18,09 & & & \\
\hline Posttest & 30 & 23,35 & 41,7 & 31,2 & 35,7164 \\
\hline
\end{tabular}

Berdasarkan tabel uji hipotesis dapat diketahui hasil data pretest kelompok eksperimen dengan rata-rata 18,09 , dan hasil data posttest kelompok eksperimen dengan rata-rata 23,35 dan diketahui juga $\Sigma$ d berjumlah $41,7, \Sigma x d$ berjumlah 31,2, dan $\Sigma \mathrm{xd}^{2}$ berjumlah 35,7164.

Berdasarkan hasil pre-test yang telah dilakukan, didapatkan hasil kecepatan tertinggi 16,21 dan kecepatan terendah 22,45 dengan mean 18,83. Setelah dilakukan tes awal (pre-test) dilakukan, selanjutnya latihan sirkuit dilakukan oleh kelompok eksperimen selama 6 minggu. Latihan sirkuit dilakukan untuk meningkatkan kemampuan dribble pada permainan sepakbola dan latihan sirkuit dalam latihannya langsung menggunakan teknik dribble. Setelah latihan sirkuit selesai selama 6 minggu, kemudian sampel melakukan tes akhir (post-test). Pada hasil post-test didapatkan hasil kecepatan tertinggi 14,54 dan kecepatan terendah 20,59 dengan mean 17,56. Berdasarkan dengan uraian yang telah disebutkan terdapat peningkatan kemampuan dribble yang didapatkan setelah para pemain diberikan perlakuan latihan sirkuit selama 6 minggu.

Berdasarkan penjelasan diatas dapat disimpulkan latihan sirkuit terhadap kemampuan dribble dalam permainan sepakbola berpengaruh karena dari latihan sirkuit yang berulang-ulang akan terdapat kemampuan dasar melatih keluwesan tubuh yang mana berguna untuk melakukan dribble sehingga membuat pemain lebih luwes dalam melakukan gerakan dribble dan melatih koordinasi.

Berdasarkan pendapat para ahli di atas dan hasil hipotesis yang diterima maka dapat disimpulkan bahwa latihan zig-zag berpengaruh terhadap kemampuan menggiring bola (dribbling). Peningkatan terjadi setelah diberi perlakuan selama 4-6 minggu sesuai dengan intensitasnya yang meningkat. Kelebihan latihan zig-zag ini dimana

Dipublikasikan Oleh :

UPT Publikasi dan Pengelolaan Jurnal

Universitas Islam Kalimantan Muhammad Arsyad Al-Banjari Banjarmasin 
sangat efektif ketika digunakan sebagai latihan untuk meningkatkan kemampuan menggiring bola (dribbling) karena unsur yang terkandung dalam latihan ini merupakan kombinasi dari banyak komponen kecepatan, kekuatan, keseimbangan, dan koordinasi gerakan. Untuk kekurangannya hampir tidak ada karena setelah dilakukan penelitian ini bahwa latihan zig-zag sangatlah efektif untuk peningkatan kemampuan menggiring bola (dribbling). Tapi tidak terlepas dari hasil yang diperoleh pada penelitian ini, faktor-faktor yang berkaitan dengan proses latihan juga sangat mempengaruhi hasil yang dicapai, seperti intensitas, durasi, volume, frekuensi dan interval dalam latihan itu sendiri. Karena masing-masing faktor tersebut turut berperan terhadap kelangsungan latihan yang terprogram. Implikasi dari penelitian ini bahwa latihan zig-zag dapat digunakan sebagai salah satu jenis latihan untuk meningkatkan kemampuang menggiring bola (dribbling).

Berdasarkan data diatas, yang didapatkan dari hasil tabel yang sudah tertera diatas terdapat Mean dari hasil pengujian hipotesis bahwa hasil posttest 23,35 lebih besar dari pada pretest 18,09 dengan selisih mean 5,36, maka terdapat perubahan setelah diberikan tratment atau latihan. Hasil pengujian hipotesis dengan menggunakan uji t, dapat diketahahui dari hasil perhitungan statistik "uji t" didapat hasil 6,8 sedangkan $\mathrm{T}_{\text {tabel }}$ adalah 1,70 yang didapatkan dari hasil tabel distribusi $\mathrm{T}$ dengan $\mathrm{dk}(30-2)=29$ dan taraf kepercayaan $95 \%(\alpha=0,05)$, tercantum dalam tabel. Kriteria pengujian hipotesis diterima Ha jika $\mathrm{T}_{\text {hitung }}>\mathrm{T}_{\text {tabel }}(1-a)$, dan tolak H0 jika $\mathrm{T}_{\text {hitung }}<\mathrm{T}_{\text {tabel }}(1-$ $a)$, karena $\mathrm{T}_{\text {hitung }}(6,8)>\mathrm{T}_{\text {tabel }}(1,70)$. Maka terdapat perbedaan yang signifikan antara pre-test dan post-test, dengan demikian maka hipotesis H0 ditolak dan hipotesis Ha diterima. Pernyataan Ha yaitu “ Ada pengaruh latihan sirkuit terhadap kemampuan dribble dalam permainan sepakbola pada SSB Putera Sukma U-15 Palembang".

\section{PENUTUP}

Berdasarkan hasil penelitian dan analisis data di atas, maka dapat diambil kesimpulan bahwa latihan sirkuit berpengaruh terhadap kemampuan driblle dalam permainan sepakbola pada SSB Putera Sukma U-15 Palembang. Dari hasil penelitian ini menunjukkan bahwa latihan sirkuit dapat digunakan sebagai metode latihan untuk meningkatkan kemampuan dribble dalam permainan sepak bola.

\subsection{Saran}

Berdasarkan simpulan di atas, maka penulis memberikan saran-saran sebagai berikut :

1. Bagi pemain, sebaiknya tetap melakukan latihan sirkuit untuk meningkatkan kemampuan dribble serta melakukan teknik dasar sepakbola lainnya.

2. Bagi guru atau pelatih, latihan sirkuit dapat digunakan sebagai metode latihan dalam meningkatkan kemampuan dribble.

3. Bagi mahasiswa penjaskes yang ingin mengadakan penelitian serupa dapat menjadikan penelitian ini sebagai bahan acuan atau informasi serta menambahkan bentuk variasi latihan.

\section{REFERENSI}

EKI, S., \& M Haris, S. (2019). Pengaruh Latihan Circuit Training Terhadap Peningkatan Volume Oksigen Maksimal Peserta Didik Kegiatan Ekstrakulikuler Sepak Bola Sekolah Menengah Atas Negeri 4 Palembang. Universitas Bina Darma.

Hartati, dkk,. (2020). Latihan Kelincahan Dan Keseimbangan Untuk Meningkatkan Hasil Dribble Sepakbola. ALTIUS : Jurnal Ilmu Olahraga dan Kesehatan, 9(01), 38-46

Mubarok, M. Z. (2018). Pengaruh Bentuk Latihan Envelope Run dan Boomerang Run Dengan Metode Latihan Repetisi Terhadap Peningkatan Kelincahan Pemain Sepak Bola. Biormatika: Jurnal Ilmiah Fakultas Keguruan Dan Ilmu Pendidikan, 4(02), 301-311.

Naldi, I. Y., \& IRawan, R. (2020). Kontribusi Kemampuan Motorik Terhadap Kemampuan Teknik Dasar Pada Atlet Ssb (Sekolah Sepakbola) Balai Baru Kota Padang. Jurnal Performa Olahraga, 5(1), 6-11.

Pratama, M., Alnedral, A., Sin, T., \& Soniawan, V. (2020). Metode Circuit Training Berpengaruh Terhadap Kemampuan Dribbling Sepakbola. Jurnal Patriot, 2(3), 874-884.

Ramli. (2021). Studi Kondisi Fisik Pemain Bola Voli pada Cub IKTLVB Kabupaten Flores Timur. Riyadhoh : Jurnal Pendidikan Olahraga, 4(01), 108-115.

Soniawan, V., \& Irawan, R. (2018). Metode Bermain Berpengaruh Terhadap Kemampuan Long Passing Sepakbola. Jurnal Performa Olahraga, 3(01), 42.

Sugiyono. (2017). Metode Penelitian Bisnis: Pendekatan Kuantitatif, Kualitatif, Kombinasi, dan R\&D. Penerbit CV. Alfabeta: Bandung.

Sukerti, N. L., Kanca, I. N., \& Sudarmada, I. N. (2017). Pengaruh Pelatihan Continuous Circuit Terhadap Volume Oksigen Maksimal (VO2 MAKS) AN KAPASITAS VITAL PARU. Jurnal Ilmu Keolahragaan Undiksha, 5(3), 11-22.

Dipublikasikan Oleh :

UPT Publikasi dan Pengelolaan Jurnal

Universitas Islam Kalimantan Muhammad Arsyad Al-Banjari Banjarmasin 
Suryadi, R. (2021). Pengaruh Permainan Target Terhadap Akurasi Shooting Pada Permainan Futsal dalam Ekstrakulikuler SMAN 2 Kota Sukabumi. Riyadhoh: Jurnal Pendidikan Olahraga 4(01), 88-90.

Sutanto, T. (2016). Buku pintar olahraga. Yogyakarta: Pustaka Baru Pres.

Udam, M. (2017). Pengaruh Latihan Shuttle-Run dan Zig-zag terhadap Kemampuan Dribbling Bola pada Siswa Sekolah Sepakbola (SSB) Imanuel USia 13-15 di Kabupaten Jayapura. Jurnal Pendidikan Jasmani Olahraga Dan Kesehatan, 3(1), 61.

Dipublikasikan Oleh :

UPT Publikasi dan Pengelolaan Jurnal

Universitas Islam Kalimantan Muhammad Arsyad Al-Banjari Banjarmasin 